\title{
COMMUNICATIONS
}

\section{FACTORS AFFECTING THE HYDRATION OF THE CORNEA IN THE EXCISED EYE AND THE LIVING ANIMAL*}

BY

\author{
MAURICE E. LANGHAM AND IRVIN S. TAYLOR $†$ \\ From the Institute of Ophthalmology, University of London
}

RECENTLY, the influence of metabolism on the water content of the excised cornea has been studied by several investigators. Schwartz, Danes, and Leinfelder (1954) immersed pieces of excised corneae in a nutrient medium and modified the metabolism by cold, lack of substrates, and the use of metabolic inhibitors. From their studies, they concluded that the mechanism regulating corneal hydration was dependent on energy derived from the aerobic and anaerobic metabolism of glucose. Davson $(1954,1955)$ studied the changes in weight and water content of corneae in excised eyes with a view to establishing whether in the living eye there is an active transport mechanism that normally prevents the uptake of aqueous humour, tears, and limbal capillary filtrate. It was observed that the corneae of eyes left for $24 \mathrm{hrs}$ in a cold moist chamber increased in water content and decreased again on warming to $31^{\circ} \mathrm{C}$., and that anoxia caused a marked increase in hydration. He concluded that his experimental results were consistent with the existence of an active transport mechanism in the cornea. Similar conclusions to those reached by these workers were reported by Langham $(1955 \mathrm{a}, \mathrm{b})$ from studies of the effect of aerobic and anaerobic metabolism on corneal thickness and of the movement of sodium and water into the cornea of the excised eye immediately after enucleation.

Philpot (1955) injected solutions of acidic and basic dyes, atropine, and inhibitors of cholinesterase, glycolysis, and respiration into the anterior chamber of excised rabbit eyes and observed their action on corneal hydration. Certain of the dyes and inhibitors led to an increased hydration but inhibitors of cholinesterase were without effect. The observation that iodoacetic acid increased corneal hydration when glycolysis was inhibited by over half led Philpot to conclude that glycolysis was necessary to the maintenance of corneal hydration. No attempt, however, was made in Philpot's study to ascertain if the action of these compounds on corneal hydration was due to an inhibition of the metabolic processes regulating corneal hydration or to a non-specific action on the permeability of the cornea to water and salt. This consideration is especially important in view of the observations of Herrmann and Hickman (1948) that iodoacetic acid in low concentrations reduced the cohesion of the epithelium to the underlying stroma.

-Received for publication May 29, 1956.

+ Present address: Massachusetts Eye and Ear Infirmary, Boston, Mass., U.S.A. 
Few studies have been made of the influence of metabolism on corneal hydration in the living animal. Smelser (1952) and Smelser and Ozanics $(1952,1953)$ deprived the corneae of human subjects and guinea-pigs of direct contact with atmospheric oxygen and observed a development of corneal haze. Further, they reported structural changes in the anterior layes s of the stroma and a marked decrease in the glycogen content of the epithelial cells in guinea-pigs wearing contact lenses. Smelser and Ozanics suggested that corneal metabolism is associated with a secretory mechanism regulating the hydration of the cornea and that the breakdown of glycogen acts as a source of energy when the oxygen supply is inadequate.

The development of corneal haze in corneae denied contact with oxygen can be related to the observations of Langham $(1951,1952)$ that in similar conditions there is an increase in the concentration of lactic acid in the cornea, and to the findings of Heald and Langham $(1953,1956)$ that the transfer of oxygen from the aqueous humour and the limbal capillaries is not sufficient to uphold the respiration of the epithelium.

The main object of the present investigation is to ascertain the influence of aerobic and anaerobic metabolism on corneal hydration in the living animal. First, the distribution of cations between the cornea, the aqueous humour, and the plasma of the living animal has been determined as a basis for understanding the influence of metabolism on the movement of salt and water from the cornea. Secondly, the rate of corneal swelling and the movement of water and sodium into and out of the cornea of the excised eye in the presence and absence of metabolic inhibitors and oxygen have been studied to gain further knowledge of the type of metabolic activity influencing corneal hydration. Experiments on the living animal, using metabolic inhibitors and oxygen-lack, have been made to ascertain the importance of metabolism in maintaining corneal hydration under normal conditions.

\section{Methods}

Adult rabbits of both sexes weighing 1.8 to $2.8 \mathrm{~kg}$. were chosen for the experimental work; where required pentobarbitone sodium solution was used for anaesthesia.

Procedure.-Eyes were enucleated immediately after death of the animal. Muscle and connective tissue adhering to the wall of the eye were cut away and after the thickness of the cornea had been measured, the eye was placed in a large boiling tube containing

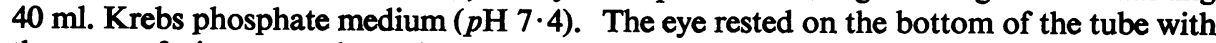
the cornea facing upwards. The medium was gassed with nitrogen, oxygen, or air through a tube with a scintered glass filter, the gas being led off through a side arm on the boiling tube.

Experiments using metabolic inhibitors on the cornea of the living rabbit were made under urethane anaesthesia. The lids of the control eye were closed with cellophane tape and the animal was placed with the experimental eye facing upwards with the lids retracted. An isotonic neutralized solution of the inhibitor was diluted with Krebs saline phosphate medium $(\mathrm{pH} 7 \cdot 4)$ to give a predetermined concentration. The solution (temperature $32-37^{\circ} \mathrm{C}$.) was then dripped on the exposed cornea. 
Analysis.-Sodium and potassium were determined by the technique of flame photometry. Extracts of corneae, aqueous humour, or plasma were obtained by adding $0.5 \mathrm{ml}$. of a solution of concentrated nitric acid to the whole cornea or to $0.2 \mathrm{ml}$. of aqueous humour or plasma. Solutions were then diluted with water. Standard solutions of sodium or potassium were run in each set of determinations. Known amounts of sodium and potassium salts added to similar extracts were quantitatively recovered in subsequent analysis.

The thickness of the cornea was measured by an apparatus similar to that described by Maurice and Giardini (1951). A standard Warburg apparatus was used to determine the rate of glycolysis and oxygen uptake of the excised cornea. Oxygen uptake was determined using $2.5 \mathrm{ml}$. Krebs saline phosphate medium $(\mathrm{pH} 7.4)$ and air or oxygen as the gas phase. The Warburg method described by Dixon (1951) was used to measure the rate of acid production. A Krebs saline bicarbonate solution (Umbreit, Burriss, and Stauffer, 1949) to which was added glucose to a concentration of $100 \mathrm{mg} . / 100 \mathrm{ml}$. was gassed with a mixture of 5 per cent. $\mathrm{CO}_{2}$ and 95 per cent. $\mathrm{N}_{2}$. The flasks, each containing one cornea, were gassed at $37^{\circ} \mathrm{C}$. for $30 \mathrm{~min}$. and then left to equilibrate for a further $30 \mathrm{~min}$. before readings were begun.

\section{Results}

The mean thickness, wet weight, hydration, and concentrations of sodium and potassium in corneae of the adult rabbit are shown in Table I. The mean percentage hydration of $75 \cdot 6 \pm 0 \cdot 20$ concurs with the mean values of $77 \cdot 7$ and 75.9 reported by Duane (1949) and Davson (1955); the corneal thickness of $0 \cdot 39 \pm$ $0.004 \mathrm{~mm}$. agrees with the mean value of $0.375 \mathrm{~mm}$. reported by Maurice and Giardini (1951), but is rather higher than the value of $0.33 \pm 0.001 \mathrm{~mm}$. reported by Maurice (1951).

\section{TABLE I}

\section{COMPOSITION OF CORNEAE OF EYES TAKEN FROM TEN NORMAL ADULI RABBITS}

$\mathrm{C}_{2}-\mathrm{C}_{1}$ and ratios $\mathrm{C}_{1} / \mathrm{C}_{2}$ calculated from results on individual rabbits. Results expressed as arithmetic mean \pm standard error of mean.

\begin{tabular}{|c|c|c|c|}
\hline Corneae & $\mathrm{C}_{1}$ & $\mathrm{C}_{2}$ & $\mathrm{C}_{1}-\mathrm{C}_{2}$ \\
\hline $\begin{array}{l}\text { Thickness (mm.) } \ldots \\
\text { Wet Weight (mg.) } \ldots \\
\text { Hydration (per cent.) } \\
\text { Na mEq./kg. } \mathrm{H}_{2} \mathrm{O} \quad \ldots \\
\mathrm{K} \text { mEq. } / \mathrm{kg} . \mathrm{H}_{2} \mathrm{O} \quad \ldots\end{array}$ & $\begin{array}{r}0.39 \pm 0.004 \\
87 \cdot 6 \pm 2 \cdot 53 \\
75 \cdot 6 \pm 0.20 \\
164 \cdot 3 \pm 3 \cdot 04 \\
24 \cdot 7 \pm 0.68\end{array}$ & $\begin{array}{r}0 \cdot 39 \pm 0 \cdot 005 \\
86 \cdot 5 \pm 2 \cdot 49 \\
75 \cdot 3 \pm 0 \cdot 16 \\
166 \cdot 8 \pm 3 \cdot 82 \\
25 \cdot 2 \pm 0 \cdot 50\end{array}$ & $\begin{array}{l}0.00 \pm 0.001 \\
-0.9 \pm 0.90 \\
-0.3 \pm 0.21 \\
2.5 \pm 1.76 \\
0.5 \pm 1.10\end{array}$ \\
\hline
\end{tabular}

The distribution of sodium and potassium between the cornea, the aqueous humour, and the plasma is recorded in Table II (overleaf). The high concentration of sodium and the low concentration of potassium in the cornea are just as expected in view of its large extracellular space. The concentration of sodium in the aqueous humour agrees with the values reported by Kinsey (1950), but the concentration of sodium in the cornea is significantly higher than that indicated by the studies of Maurice (1951) on the distribution of ${ }^{24} \mathrm{Na}$ between the cornea and the aqueous humour.

A further similar series of analyses was made of the distribution of total sodium and ${ }^{24} \mathrm{Na}$ between the three tissues $20 \mathrm{hrs}$ after the intravenous injection of a 0.9 
TABLE II

DISTRIBUTION OF SODIUM AND POTASSIUM BETWEEN CORNEA, AQUEOUS HUMOUR, AND PLASMA OF FIVE ADULT RABBITS

Results expressed as mEq./kg. $\mathrm{H}_{2} \mathrm{O}$. Ratios calculated from results on individual rabbits.

\begin{tabular}{|c|c|c|c|c|c|c|}
\hline & & Cornea & $\begin{array}{l}\text { Aqueous } \\
\text { Humour }\end{array}$ & Plasma & C/Aq. & Aq./Pl. \\
\hline $\begin{array}{l}\text { Sodium } \\
\text { Potassium }\end{array}$ & $\begin{array}{l}\ldots \\
\ldots\end{array}$ & $\begin{aligned} 170 \cdot 6 & \pm 2 \cdot 51 \\
25 \cdot 0 & \pm 0 \cdot 41\end{aligned}$ & $\begin{array}{r}141 \cdot 5 \pm 0.79 \\
4 \cdot 7 \pm 0.15\end{array}$ & $\begin{array}{r}152 \cdot 8 \pm 1 \cdot 79 \\
5 \cdot 35 \pm 0.33\end{array}$ & $1 \cdot 22 \pm 0.02$ & $\begin{array}{l}0.93 \pm 0.006 \\
0 \cdot 89 \pm 0.03\end{array}$ \\
\hline
\end{tabular}

per cent. (w/v) solution of sodium chloride containing ${ }^{24} \mathrm{Na}$. Table III shows that at $20 \mathrm{hrs}$ the ${ }^{24} \mathrm{Na}$ was within a few per cent. of dynamic equilibrium. The distribution ratio between the cornea and the aqueous humour for both ${ }^{24} \mathrm{Na}$ and total sodium agreed with the results in Table II.

TABLE III

DISTRIBUTION OF ${ }^{24} \mathrm{NA}$ AND TOTAL SODIUM BETWEEN CORNEA, AQUEOUS HUMOUR, AND PLASMA 20 HRS AFTER INTRAVENOUS INJECTION OF 20 ML. 1 PER CENT. SOLUTION OF RADIOACTIVE SODIUM CHLORIDE

Ratio Aq./Pl. calculated from concentration $/ \mathrm{kg}$. $\mathrm{H}_{2} \mathrm{O}$; ratio $\mathrm{C} / \mathrm{Aq}$. calculated from concentration $/ \mathbf{k g}$. tissue to simplify comparison with published data.

\begin{tabular}{c|c|c|c|c}
\hline Rabbit & ${ }^{24} \mathrm{Na}$ C/Aq. & Total Na C/Aq. & ${ }^{24} \mathrm{Na}$ Aq./Pl. & Total Na Aq./Pl. \\
\hline 1 & $0.82 ; 0.90$ & $0.91 ; 0.92$ & $0.95 ; 0.92$ & $0.93 ; 0.93$ \\
2 & $0.91 ; 0.88$ & $0.88 ; 0.91$ & $0.97 ; 0.95$ & $0.97 ; 0.93$ \\
3 & $0.81 ; 0.87$ & $0.92 ; 0.90$ & $0.89 ; 0.86$ & $0.92 ; 0.94$ \\
4 & $0.89 ; 0.88$ & $0.88 ; 0.88$ & $0.94 ; 0.94$ & $0.97 ; 0.93$ \\
5 & $0.88 ; 0.84$ & $0.92 ; 0.90$ & $0.97 ; 0.95$ & $0.93 ; 0.94$ \\
\hline Mean & $0.87 \pm 0.010$ & $0.90 \pm 0.005$ & $0.93 \pm 0.012$ & $0.94 \pm 0.005$ \\
\hline
\end{tabular}

Swelling of the Cornea in the Excised Eye.-In all experiments the eye was placed in Krebs saline phosphate $(p H \mathbf{H} \cdot 4)$. The concentration of sodium in this medium is approximately equal to that in the aqueous humour, but the concentration of the main anion, chloride, is nearly 20 per cent. below that in the aqueous humour.

The extent of corneal swelling in the presence of oxygen at five temperatures is shown in Fig. 1 (opposite). Between 25 and $37.5^{\circ} \mathrm{C}$. the cornea thickened and approached a new state of equilibrium within 2-3 hrs. In this temperature range the swelling was maximal at $25^{\circ} \mathrm{C}$. at a mean thickness of 15 per cent. above its initial value. At $15^{\circ} \mathrm{C}$. the cornea continued to increase in thickness over the whole experimental period. The mean rate of swelling of 4 per cent. $\mathrm{hr}^{-1}$ of the initial thickness was, however, less than the value of 5.5 per cent. $\mathrm{hr}^{-1}$ recorded at a temperature of $10^{\circ} \mathrm{C}$. At $40^{\circ} \mathrm{C}$. there was a small increase in the corneal thickness of 1-3 per cent. The relation between the extent of corneal swelling and temperature is of especial interest in that the marked change in metabolism which presumably occurs over this range of temperatures $\left(25-40^{\circ} \mathrm{C}\right.$.) was accompanied by only a small increase in corneal thickness. 

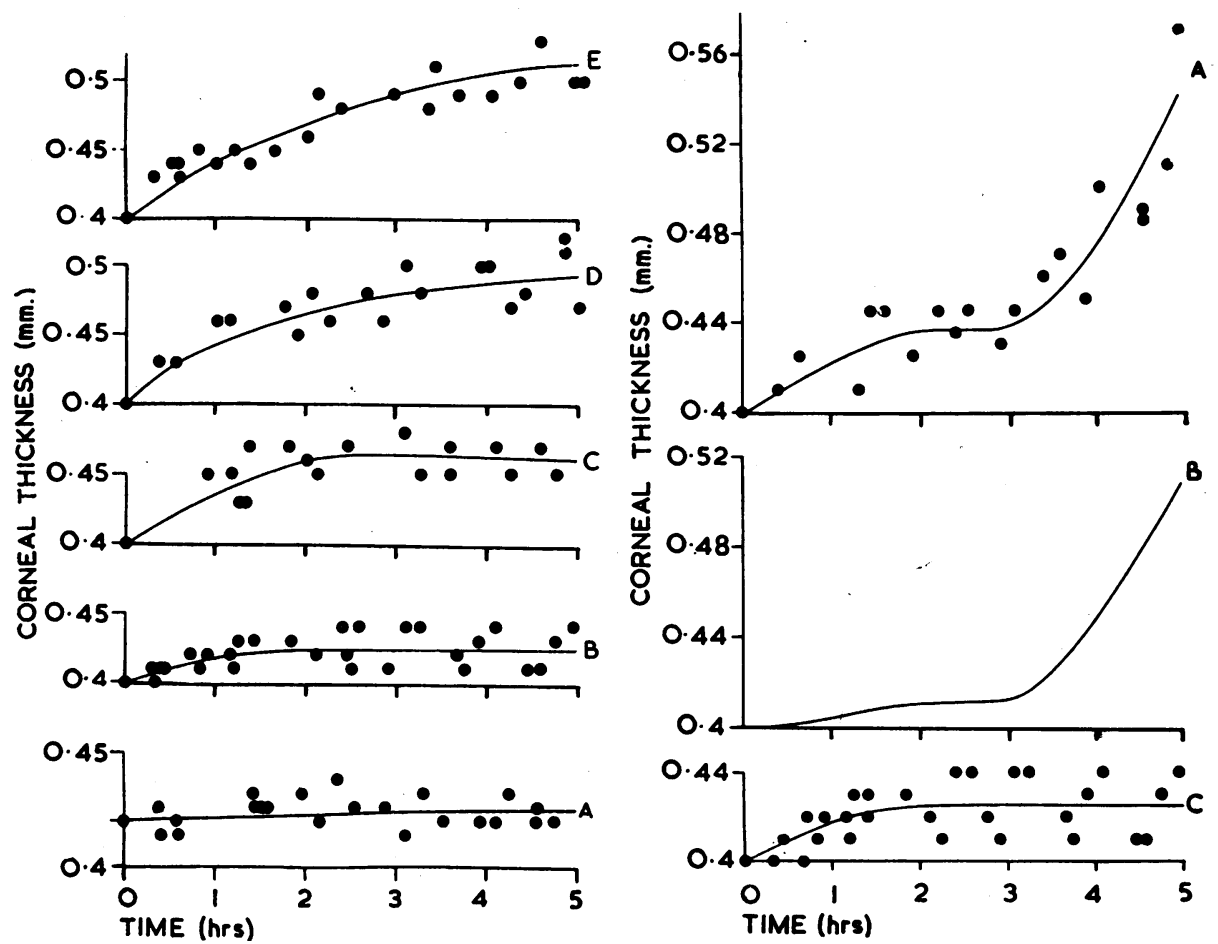

Fig. 1.-Effect of temperature on swelling of cornea of excised eye immersed in Krebs phosphate medium gassed with oxygen. Each curve is derived from the results in four eyes. Curve $A$ at $40^{\circ} \mathrm{C}$. Curve $B$ at $37.5^{\circ} \mathrm{C}$. Curve $C$ at $25^{\circ} \mathrm{C}$. Curve $\mathrm{D}$ at $15^{\circ} \mathrm{C}$. Curve $\mathrm{E}$ at $10^{\circ} \mathrm{C}$.

Fig. 2.-Effect of lack of oxygen on swelling of cornea of excised eye immersed in Krebs phosphate medium. Curves A and $C$ record corneal thickness in the absence and presence of oxygen respectively. Curve $B$ is derived from Curves $A$ and $C$ to show corneal swelling due to lack of oxygen.

The effect of oxygen-lack on the cornea was made in similar experiments in which the medium was kept at $37.5^{\circ} \mathrm{C}$. and gassed with nitrogen. In these experiments, to ensure that anaerobic conditions were obtained within a few minutes of placing the eye in the medium, a rapid stream of wet nitrogen was passed through the medium for $30 \mathrm{~min}$. before the start of the experiment. The results are shown in Fig. 2, and it will be seen that the swelling curve comprises two distinctly different phases. To begin with little swelling took place and scarcely differed from that observed in the presence of oxygen. On the other hand, at the end of this first phase, the thickness of the central area of the cornea started to increase rapidly, and the rate of swelling approached 15 per cent. $\mathrm{hr}^{-1}$ of its initial thickness. This increase could not, however, have been due to a decreased rate of anaerobic glycolysis for the added glucose was sufficient to maintain glycolysis at its maximal rate for many hours (Langham, 1954). The finding that the corneal hydration can be maintained approximately constant for 2-3 hrs in the absence of oxygen is consistent with the view of Smelser and Ozanics (1953) that there is an energy reserve in the cornea which may be utilized to prevent corneal swelling.

The changes in hydration, thickness, and wet weight of the cornea in the absence 
and presence of oxygen are recorded in Tables IV A-D. In the first $2 \frac{1}{2}$-hr period, there were mean increases in wet weight of 11.3 and 14.3 per cent. in the presence and absence of oxygen respectively. These increases exceed the changes in corneal

TABLE IV A

\section{EFFECT OF AEROBIC METABOLISM ON COMPOSITION OF CORNEA IN EXCISED EYES}

Control eyes analysed at zero time. Second eye placed in saline phosphate medium for $2 \frac{1}{2} \mathrm{hrs}$ at $37 \cdot 5^{\circ} \mathrm{C}$.

\begin{tabular}{|c|c|c|c|}
\hline Time (hrs) & 0 & $2 \frac{1}{2}$ & Increases $\left(0-2 \frac{1}{2} \mathrm{hrs}\right)$ \\
\hline $\begin{array}{l}\text { Thickness (mm.) } \ldots \\
\text { Hydration (per cent.) } \\
\text { Wet Weight (mg.) } \\
\text { Na mEq./kg. } \mathrm{H}_{2} \mathrm{O} \quad \ldots\end{array}$ & $\begin{array}{r}0 \cdot 38 \pm 0 \cdot 01 \\
76 \cdot 2 \pm 0 \cdot 28 \\
75 \cdot 7 \pm 4 \cdot 19 \\
175 \cdot 1 \pm 1 \cdot 47\end{array}$ & $\begin{array}{r}0.41 \pm 0.01 \\
77.8 \pm 0.31 \\
84.2 \pm 5.45 \\
175.5 \pm 1.74\end{array}$ & $\begin{array}{l}0.03 \pm 0 \cdot 004 \\
1 \cdot 62 \pm 0 \cdot 28 \\
8 \cdot 50 \pm 1 \cdot 39 \\
0.40 \pm 2.06\end{array}$ \\
\hline
\end{tabular}

TABLE IV B

EFFECT OF OXYGEN-LACK ON COMPOSITION OF CORNEA IN EXCISED EYES Çontrol eyes analysed at zero time. Experimental procedure as in Table IVA.

\begin{tabular}{|c|c|c|c|}
\hline Time (hrs) & 0 & $2 \frac{1}{2}$ & Increases $\left(0-2 \frac{1}{2} \mathrm{hrs}\right)$ \\
\hline $\begin{array}{l}\text { Thickness (mm.) } \\
\text { Hydration (per cent.) } \\
\text { Wet Weight (mg.) } \\
\text { Na mEq./kg. } \mathrm{H}_{2} \mathrm{O}\end{array}$ & $\begin{array}{r}0.37 \pm 0.01 \\
76 \cdot 6 \pm 0.37 \\
76 \cdot 3 \pm 3 \cdot 54 \\
179.6 \pm 2.96\end{array}$ & $\begin{array}{r}0.42 \pm 0.01 \\
79.9 \pm 0.55 \\
87 \cdot 2 \pm 3 \cdot 57 \\
173.1 \pm 2.88\end{array}$ & $\begin{array}{c}0.05 \pm 0.010 \\
3.3 \pm 0.45 \\
10.9 \pm 1.01 \\
-6.5 \pm 2.4\end{array}$ \\
\hline
\end{tabular}

TABLE IV C

COMPOSITION OF CORNEAE OF EXCISED EYES IMMERSED IN SAI.INE PHOSPHATE MEDIUM ( $p \mathrm{H} 7 \cdot 4$; TEMP. $37 \cdot 5^{\circ} \mathrm{C}$.) GASSED WITH $\mathrm{O}_{2}$ Eyes removed at $2 \frac{1}{2}$ and $5 \mathrm{hrs}$ respectively

\begin{tabular}{|c|c|c|c|}
\hline Time (hrs) & $2 \frac{1}{2}$ & 5 & Increases $\left(2 \frac{1}{2}-5 \mathrm{hrs}\right)$ \\
\hline $\begin{array}{l}\text { Thickness (mm.) } \\
\text { Hydration (per cent.) } \\
\text { Wet Weight (mg.) } \\
\text { Na mEq./kg. } \text { H. }_{2} \mathrm{O}\end{array}$ & $\begin{array}{r}0.41 \pm 0.01 \\
78.7 \pm 0.25 \\
84.0 \pm 2.85 \\
183.8 \pm 4.03\end{array}$ & $\begin{array}{r}0.39 \pm 0.01 \\
77.7 \pm 0.36 \\
83.1 \pm 2.86 \\
188.9 \pm 3.98\end{array}$ & $\begin{array}{l}-0.02 \pm 0.003 \\
-1.0 \pm 0.20 \\
-0.91 \pm 0.74 \\
5.1 \pm 4.35\end{array}$ \\
\hline
\end{tabular}

TABLE IV D

COMPOSITION OF CORNEAE OF EXCISED EYES IMMERSED IN SALINE PHOSPHATE MEDIUM ( $p \mathrm{H} 7 \cdot 4$; TEMP. $37 \cdot 5^{\circ} \mathrm{C}$.) GASSED WITH $\mathrm{N}_{2}$

Eyes removed at $2 \frac{1}{2}$ and $5 \mathrm{hrs}$ respectively

\begin{tabular}{|c|c|c|c|}
\hline Time (hrs) & $2 \frac{1}{2}$ & 5 & Increases $\left(2 \frac{1}{2}-5 \mathrm{hrs}\right)$ \\
\hline $\begin{array}{l}\text { Thickness (mm.) } \\
\text { Hydration (per cent.) } \\
\text { Wet Weight (mg.) } \\
\text { Na mEq. } / \mathrm{kg} . \mathrm{H}_{2} \mathrm{O}\end{array}$ & $\begin{array}{r}0.47 \pm 0.01 \\
79.5 \pm 0.35 \\
116.6 \pm 3.30 \\
169.5 \pm 2.40\end{array}$ & $\begin{array}{r}0.56 \pm 0.02 \\
81 \cdot 7 \pm 0.31 \\
129.0 \pm 8 \cdot 17 \\
173.0 \pm 3.07\end{array}$ & $\begin{array}{c}0.09 \pm 0.020 \\
2.2 \pm 0.44 \\
12.4 \pm 3 \cdot 83 \\
3 \cdot 5 \pm 3 \cdot 6\end{array}$ \\
\hline
\end{tabular}


thickness measured in the central area which shows that the rate of swelling was not the same over the whole corneal surface. As the changes were not accompanied by a change in the concentration of sodium, there must have been a proportionate net movement of sodium into the cornea. The mean rate of swelling per hour was 4.5 and 5.7 per cent. of the initial weight in the presence and absence of oxygen respectively.

In the second $2 \frac{1}{2}-\mathrm{hr}$ period, absence of oxygen had a marked action on the cornea, and the wet weight increased by 10.6 per cent. In the presence of oxygen no increase at all occurred. Again corneal swelling was not accompanied by any significant change in the concentration of sodium. In the same period, Table IV $\mathrm{C}$ shows there was a tendency for the cornea to recover from its swollen state in the presence of oxygen, a decrease in corneal hydration of 1 per cent. being recorded; this recovery phase has been repeatedly observed.

The net movement of sodium into the corneae in these experiments has been calculated from the mean increase in corneal weight and the knowledge that the sodium concentration remained unchanged, even though accompanied by changes in corneal hydration. Expressed as mol. of sodium transferred into $100 \mathrm{mg}$. wet tissue per min. the following results were obtained:

\begin{tabular}{|c|c|c|}
\hline Time (hrs) & $0-2 \frac{1}{2}$ & $2 \frac{1}{2}-5$ \\
\hline $\begin{array}{l}\mathbf{N}_{2} \\
\mathbf{O}_{2}\end{array}$ & $\begin{array}{l}1 \cdot 71 \times 10^{-8} \mathrm{~mol} . \mathrm{min}^{-1} \\
1.24 \times 10^{-8} \mathrm{~mol} . \mathrm{min}^{-1}\end{array}$ & $\begin{array}{c}1.21 \times 10^{-8} \mathrm{~mol} . \mathrm{min}^{-1} \\
0\end{array}$ \\
\hline
\end{tabular}

The rate and extent of recovery of the cornea from a swollen state induced by leaving the excised eye in Krebs saline phosphate at $4^{\circ} \mathrm{C}$. for $16 \mathrm{hrs}$ are shown in Fig. 3.

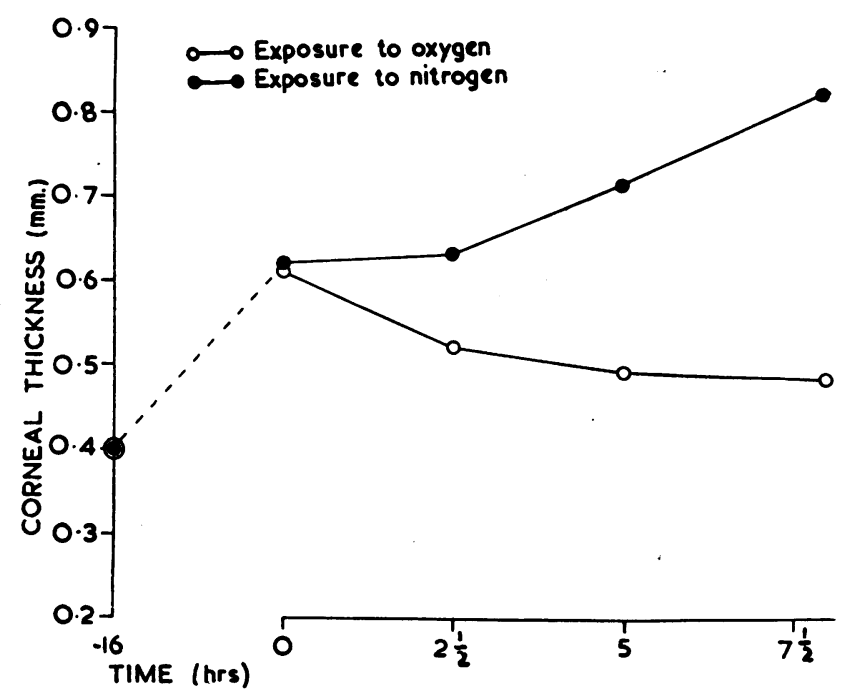

FIG. 3.- Reversal of cold-induced swelling by aerobic metabolism. Corneae having a mean initial thickness of $0.40 \mathrm{~mm}$. were cooled for $16 \mathrm{hrs}$ in Krebs phosphate medium. The temperature was then raised to $37.5^{\circ} \mathrm{C}$. and oxygen or nitrogen
bubbled through. Mean of four corneae. 
The corneal thickness increased to a mean value of $0.63 \mathrm{~mm}$. from an initial mean value of $0.40 \mathrm{~mm}$., and on warming to $37.5^{\circ} \mathrm{C}$. in the presence of oxygen a rapid decrease in corneal thickness occurred. The final mean corneal thickness was $0.50 \mathrm{~mm}$. (i.e. $0.10 \mathrm{~mm}$. above the initial thickness), and exceeded the mean increase of $0.03 \mathrm{~mm}$. observed when the excised eye was placed directly in the medium at $37.5^{\circ} \mathrm{C}$. containing oxygen (see Fig. 1). Probably, this difference reflects an increased permeability due to the gross swelling caused by leaving the eye for $16 \mathrm{hrs}$ at $4^{\circ} \mathrm{C}$. In the absence of oxygen the corneal thickness remained constant for 2-3 hrs. After this a continuous swelling of the cornea was observed over the remainder of the experimental period of $8 \mathrm{hrs}$.

The change in the composition of the cornea under these conditions is recorded in Tables V A-C. In the presence of oxygen, there was a significant decrease in the corneal weight and hydration but no change in the concentration of sodium. In the absence of oxygen, the corneal metabolism was adequate to prevent an increase in hydration and wet weight for at least $2 \frac{1}{2} \mathrm{hrs}$. After this time hydration and wet weight increased, but again there was no change in the concentration of sodium. There was no net transfer of sodium in the first $2 \frac{1}{2}$ hrs in the absence of oxygen, but in the same period there was a mean movement outwards of $1.32 \times 10^{-8} \mathrm{~mol}$ min..$^{-1}$ of sodium per $100 \mathrm{mg}$. wet tissue in the presence of oxygen.

TABLE V A

COMPOSITION OF CORNEAE AFTER 16 HRS AT $4^{\circ} \mathrm{C}$. (CORNEA 1) FOLLOWED BY $2 \frac{1}{2}$ HRS AT $37 \cdot 5^{\circ} \mathrm{C}$. (MEDIUM GASSED WITH $\mathrm{O}_{2}$ )

\begin{tabular}{|c|c|c|c|}
\hline Cornea & 1 & 2 & Increases $\left(16-18 \frac{1}{2} \mathrm{hrs}\right)$ \\
\hline $\begin{array}{l}\text { Thickness (mm.) } \ldots \\
\text { Hydration (per cent.) } \\
\text { Wet Weight (mg.) } \ldots \\
\text { Na mEq./kg. } \mathrm{H}_{2} \mathrm{O} \quad \ldots\end{array}$ & $\begin{array}{r}0.63 \pm 0.01 \\
83.9 \pm 0.21 \\
130.9 \pm 6 \cdot 88 \\
162.4 \pm 1 \cdot 15\end{array}$ & $\begin{array}{r}0.53 \pm 0.02 \\
82 \cdot 0 \pm 0 \cdot 25 \\
114 \cdot 9 \pm 6 \cdot 65 \\
163 \cdot 1 \pm 1 \cdot 94\end{array}$ & $\begin{aligned}-0.10 & \pm 0.004 \\
-1.9 & \pm 0.13 \\
-16.0 & \pm 0.38 \\
-1.3 & \pm 0.74\end{aligned}$ \\
\hline
\end{tabular}

TABLE V B

COMPOSITION OF CORNEAE AFTER 16 HRS AT $4^{\circ} \mathrm{C}$. (CORNEA 1) FOLLOWED BY $2 \frac{1}{2}$ HRS AT $37 \cdot 5^{\circ} \mathrm{C}$. (MEDIUM GASSED WITH $\mathrm{N}_{2}$ )

\begin{tabular}{|c|c|c|c|}
\hline Cornea & 1 & 2 & Increases $\left(16-18 \frac{1}{2} \mathrm{hrs}\right)$ \\
\hline $\begin{array}{l}\text { Thickness (mm.) } \ldots \\
\text { Hydration (per cent.) } \\
\text { Wet Weight (mg.) } \ldots \\
\text { Na mEq./kg. } \mathrm{H}_{2} \mathrm{O} \quad \ldots\end{array}$ & $\begin{array}{r}0.59 \pm 0.01 \\
83 \cdot 6 \pm 0.51 \\
134 \cdot 0 \pm 8 \cdot 62 \\
159 \cdot 5 \pm 3 \cdot 04\end{array}$ & $\begin{array}{r}0.58 \pm 0 \cdot 01 \\
84 \cdot 0 \pm 0 \cdot 25 \\
134 \cdot 9 \pm 8 \cdot 10 \\
168 \cdot 1 \pm 2 \cdot 25\end{array}$ & $\begin{array}{c}-0.01 \pm 0.000 \\
0.4 \pm 0.07 \\
0.9 \pm 1.60 \\
8.6 \pm 0.63\end{array}$ \\
\hline
\end{tabular}

TABLE V C

COMPOSITION OF CORNEAE AFTER 16 HRS AT $4^{\circ} \mathrm{C}$. (CORNEA 1) FOLLOWED BY 8 HRS $、 A T ~ 37 \cdot 5^{\circ} \mathrm{C}$. (MEDIUM GASSED WITH $\mathrm{N}_{2}$ )

\begin{tabular}{l|c|c|c}
\hline Cornea & 1 & 2 & Increases (16-24 hrs) \\
\hline Thickness (mm.) $\ldots$ & $0.65 \pm 0.02$ & $0.82 \pm 0.02$ & $0 \cdot 17 \pm 0.04$ \\
Hydration (per cent.) & $84.2 \pm 0.24$ & $86.6 \pm 0.56$ & $2.4 \pm 1.37$ \\
Wet Weight (mg.) … & $145.0 \pm 11 \cdot 2$ & $170.8 \pm 10.7$ & $25 \cdot 8 \pm 5.2$ \\
Na. mEq./kg. H.O... & $163.2 \pm 0.82$ & $169.1 \pm 1.82$ & $5.9 \pm 1.37$ \\
\hline
\end{tabular}


Effect of Metabolic Inhibitors on the Cornea in the Excised eye and the Living Animal.-The rate of oxygen uptake of excised rabbit cornea in Krebs phosphate medium containing $2: 4$ dinitrophenol (DNP) is recorded in Table VI. The results show that DNP stimulates the oxygen uptake of the cornea at a concentration of $1 \times 10^{-4} \mathrm{M}$ and depresses it at higher concentrations. The oxygen uptake recorded on control cornea is significantly less than the mean value of $0.864 \pm 0.035$ (27) recorded in an earlier study (Langham, 1952) in which no medium was used. The low values in the control series could, therefore, be due to the bathing fluid. To test this possibility, corneae from two rabbits were divided into two groups and the oxygen uptake measured in the absence and presence of the medium; the value of $\mathrm{QO}_{2}$ for corneae immersed in the medium with air as a gas phase was 0.41 and for those without a medium it was 0.78 . The mean oxygen uptake of four corneae immersed in the medium with pure oxygen as the gas phase was $0 \cdot 82 \pm 0 \cdot 05$.

TABLE VI

OXYGEN UPTAKE OF EXCISED RABBIT CORNEAE IMMERSED IN 2.5 ML. KREBS PHOSPHATE MEDIUM ( $p \mathrm{H} 7 \cdot 4)$ CONTAINING $2: 4$ DINITROPHENOL

Glucose added to medium to give initial concentration of $100 \mathrm{mg} . / 100 \mathrm{ml}$. Gas phase air. Temperature at $37 \cdot 5^{\circ} \mathrm{C}$.

\begin{tabular}{c|c|c}
\hline Concentration & Experimental Cornea (DNP) & Control Cornea \\
\hline $1 \times 10^{-4} \mathrm{M}$ & $0.634 \pm 0.07(6)$ & $0.409 \pm 0.03(6)$ \\
$3 \times 10^{-4} \mathrm{M}$ & $0.328 \pm 0.08(6)$ & $0.428 \pm 0.03(6)$ \\
$1 \times 10^{-3} \mathrm{M}$ & $0.111 \pm 0.02(6)$ & $0.434 \pm 0.07(6)$ \\
\hline
\end{tabular}

In similar experiments, DNP was shown not to affect the rate of anaerobic glycolysis in the excised cornea immersed in a Krebs bicarbonate medium containing glucose. In a series of six rabbits the mean rate of anaerobic glycolysis, expressed as $\mu 1 . \mathrm{CO}_{2}$ evolved per mg. dry tissue $\mathrm{hr}^{-1}$ was $2 \cdot 51 \pm 0 \cdot 12$ in the control corneae and $2 \cdot 56 \pm 0 \cdot 15$ in corneae exposed to DNP at a concentration of $1 \times 10^{-3} \mathrm{M}$. The rate of corneal glycolysis in the controls agrees with that recorded in an earlier study (Langham 1954).

The effect of DNP on the thickness and weight of corneae of excised eyes is recorded in Tables VII $A$ and B (overleaf). At $1 \times 10^{-4}$ M DNP no corneal swelling was observed, but at a concentration of $3 \times 10^{-4} \mathrm{M}$ swelling took place. With a concentration of $1 \times 10^{-2} \mathrm{M}$ DNP there was corneal damage and loosening of the epithelial layer.

In an experimental period of $5 \mathrm{hrs}$ the extent of swelling caused by DNP was found to be similar to that resulting from lack of oxygen; thus, in a series of four pairs of eyes, the mean weight of corneae in a medium gassed with oxygen and containing a concentration of $1 \times 10^{-3} \mathrm{M} 2: 4$ dinitrophenol was $106 \pm 10 \cdot 34 \mathrm{mg}$. and of those immersed in the medium gassed with nitrogen and having no DNP it was $101 \cdot 0 \pm 5 \cdot 34 \mathrm{mg}$. A more detailed investigation of the change in corneal thickness in similar conditions indicates, however, that the swelling due to DNP differed from that caused by lack of oxygen; this is shown in Figs $4 \mathrm{~A}$ and $4 \mathrm{~B}$ (overleaf).

DNP resulted in a continued swelling over the whole experimental period, while in the absence of oxygen little corneal swelling occurred during the first $3 \mathrm{hrs}$.

The effect of DNP on the cornea of the living animal was observed by allowing a 
TABLE VII A

EFFECT OF $2: 4$ DINITROPHENOL ON CORNEAL THICKNESS OF EYES IMMERSED IN KREBS PHOSPHATE MEDIUM GASSED WITH OXYGEN AT $37 \cdot 5^{\circ} \mathrm{C}$.

$C_{1}$ represents control cornea and $C_{2}$ cornea exposed to drug. Readings taken at centre of cornea

\begin{tabular}{|c|c|c|c|}
\hline Concentration (DNP) & Time (hrs) & $\mathrm{C}_{1}(\mathrm{~mm})$. & $\mathrm{C}_{2}(\mathrm{~mm})$. \\
\hline $1 \times 10^{-4} \mathrm{M}$ & $\begin{array}{l}0 \\
2 \frac{1}{2} \\
5\end{array}$ & $\begin{array}{l}0.43 \pm 0.011 \\
0.45 \pm 0.013 \\
0.45 \pm 0.016\end{array}$ & $\begin{array}{l}0.43 \pm 0.012 \\
0.47 \pm 0.011 \\
0.47 \pm 0.015\end{array}$ \\
\hline $3 \times 10^{-4} \mathrm{M}$ & $\begin{array}{l}0 \\
2 \frac{1}{2} \\
5\end{array}$ & $\begin{array}{l}0.46 \pm 0.012 \\
0.51 \pm 0.015 \\
0.51 \pm 0.015\end{array}$ & $\begin{array}{l}0.46 \pm 0.012 \\
0.55 \pm 0.014 \\
0.60 \pm 0.017\end{array}$ \\
\hline $7 \times 10^{-4} \mathrm{M}$ & $\begin{array}{l}0 \\
2 \frac{1}{2} \\
5\end{array}$ & $\begin{array}{l}0.41 \pm 0.011 \\
0 \cdot 42 \pm 0.012 \\
0 \cdot 42 \pm 0.011\end{array}$ & $\begin{array}{l}0.41 \pm 0.011 \\
0.49 \pm 0.011 \\
0.64 \pm 0.011\end{array}$ \\
\hline $10 \times 10^{-4} \mathrm{M}$ & $\begin{array}{l}0 \\
2 \frac{1}{2} \\
5\end{array}$ & $\begin{array}{l}0 \cdot 39 \pm 0.010 \\
0 \cdot 44 \pm 0 \cdot 012 \\
0 \cdot 43 \pm 0.014\end{array}$ & $\begin{array}{l}0.39 \pm 0.010 \\
0 \cdot 50 \pm 0.012 \\
0.62 \pm 0.014\end{array}$ \\
\hline
\end{tabular}

TABLE VII B

EFFECT OF $2: 4$ DINITROPHENOL ON CORNEAL WEIGHT OF EXCISED EYES IMMERSED IN KREBS PHOSPHATE MEDIUM GASSED WITH OXYGEN AT $37 \cdot 5^{\circ} \mathrm{C}$.

$C_{1}$ represents control corneae and $C_{2}$ experimental corneae. Readings taken after $5 \mathrm{hrs}$.

\begin{tabular}{|c|c|c|c|}
\hline Concentration (DNP) & $\mathrm{C}_{1}$ (mg.) & $\mathrm{C}_{\mathrm{z}}$ (mg.) & Difference $\left(C_{2}-C_{1}\right)$ \\
\hline $\begin{aligned} 1 & \times 10^{-4} \mathrm{M} \\
3 & \times 10^{-4} \mathrm{M} \\
7 & \times 10^{-4} \mathrm{M} \\
10 & \times 10^{-4} \mathrm{M}\end{aligned}$ & $\begin{array}{r}95 \cdot 0 \pm 4 \cdot 1 \\
119 \cdot 0 \pm 2 \cdot 7 \\
97 \cdot 0 \pm 6 \cdot 9 \\
101 \cdot 0 \pm 4 \cdot 4\end{array}$ & $\begin{array}{r}94 \cdot 3 \pm 4 \cdot 6 \\
138 \cdot 4 \pm 3 \cdot 7 \\
136 \cdot 0 \pm 10 \cdot 3 \\
137 \cdot 0 \pm 5 \cdot 1\end{array}$ & $\begin{array}{c}0 \cdot 66 \pm 1 \cdot 34 \\
19 \cdot 0 \pm 4 \cdot 2 \\
39 \cdot 0 \pm 4 \cdot 3 \\
36 \cdot 0 \pm 3 \cdot 1\end{array}$ \\
\hline
\end{tabular}

solution of warm oxygenated Krebs phosphate medium containing the drug to drip continuously over the cornea at a rate of approximately $1 \mathrm{ml}$. every $10 \mathrm{~min}$. Without DNP the mean weight of four corneae removed from four rabbits was $97.5 \pm 2.9 \mathrm{mg}$., and of four corneae from the same animals $2 \frac{1}{2} \mathrm{hrs}$ after dripping Krebs phosphate medium onto the eye it was $97 \cdot 7 \pm 2 \cdot 0 \mathrm{mg}$. No swelling took place with DNP; at a concentration of $1 \times 10^{-3} \mathrm{M}$ DNP solution, the mean wet weight of the control corneae of six rabbits was $101.6 \pm 7.9 \mathrm{mg}$. and that of the experimental corneae removed after $2 \cdot 5 \mathrm{hrs}$ was $103 \cdot 0 \pm 9 \cdot 2 \mathrm{mg}$.

The ability of iodoacetic acid to inhibit corneal glycolysis has been reported by Herrmann and Hickman (1948) and Philpot (1955). In Warburg studies, the rate of anaerobic glycolysis in six control corneae, expressed as $\mu 1 . \mathrm{CO}_{2}$ evolved per mg. dry tissue $\mathrm{hr}^{-1}$, was $2 \cdot 14 \pm 0.09$, and $0 \cdot 18 \pm 0 \cdot 17$ in six corneae exposed to a concentration of $1 \times 10^{-3} \mathrm{M}$ iodoacetic acid. At a concentration of $1 \times 10^{-4} \mathrm{M}$ iodoacetic acid, the rate of anaerobic glycolysis was $0 \cdot 52 \pm 0 \cdot 14$. These values are in general agreement with those of Philpot (1955), who reported a 69-77 per cent. inhibition of corneal glycolysis at concentrations of 1 to $3 \cdot 3 \times 10^{-4} \mathrm{M}$ and a 50 per cent. inhibition at a concentration of $5 \times 10^{-5} \mathrm{M}$.

In the presence of oxygen, a concentration of $5 \times 10^{-4} \mathrm{M}$ iodoacetic acid caused 
Fig. 4.- (A) Effect of $1 \times 10^{-3}$ M $2: 4$ dinitrophenol on thickness of corneae of excised eyes in presence of oxygen. (B) Extent of swelling due to $2: 4$ dinitrophenol (upper curve) compared with extent of swelling due to absence of oxygen (lower curve).

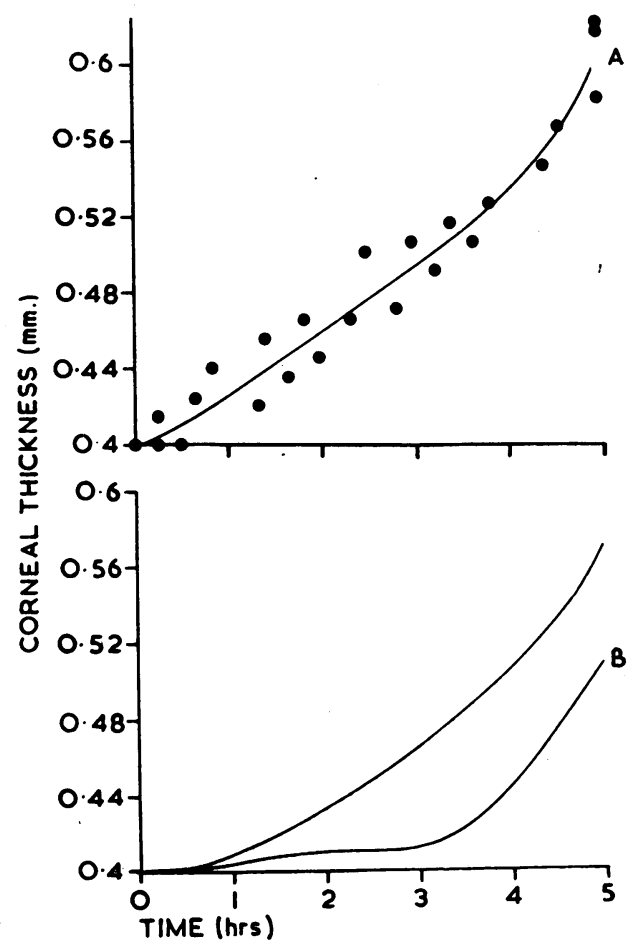

no swelling of the cornea, while a concentration of $5 \times 10^{-3} \mathrm{M}$ caused a loosening of the epithelial layer and marked opacification of the superficial area of the cornea. At a concentration of $1 \times 10^{-3} \mathrm{M}$ iodoacetic acid, loosening of the epithelium and clouding of the cornea occurred in some experiments but there was no appreciable corneal swelling. At this concentration, the mean weight of control corneae $5 \mathrm{hrs}$ after immersion in the medium was $107 \cdot 4 \pm 9 \cdot 6(5) \mathrm{ntg}$. and the experimental corneae $111 \cdot 0 \pm 9 \cdot 7(5) \mathrm{mg}$; the mean increase in wet weight of corneae taken from pairs of eyes was $3 \cdot 6 \pm 2 \cdot 0 \mathrm{mg}$. Correspondingly, the corneal thickness of the control eyes at this time was $0.48 \pm 0.011 \mathrm{~mm}$. and the experimental corneae $0.50 \pm 0.013 \mathrm{~mm}$.

In similar experiments made in the absence of oxygen, iodoacetic acid at a concentration of $5 \times 10^{-3} \mathrm{M}$ caused the epithelial layer to stain with fluorescein in all eyes. In spite of the loosening of the epithelial layer there was no significant increase in the weight of the corneae of two eyes exposed to $1 \times 10^{-3} \mathrm{M}$ iodoacetic acid. There was however an increased thickness of the central area of the corneae of the experimental eyes at $5 \mathrm{hrs}$. At $5 \times 10^{-4} \mathrm{M}$ iodoacetic acid, the control and experimental eyes reacted in a similar manner. The mean weight of the control corneae at $5 \mathrm{hrs}$ was $125 \cdot 5 \pm 3 \cdot 2(4) \mathrm{mg}$. and that of the experimental corneae $131 \cdot 0 \pm 3 \cdot 7$ (4) mg. The corneal thickness of the control eyes at $5 \mathrm{hrs}$ was $0.58 \pm$ $0.02 \mathrm{~mm}$. and that of the experimental eyes $0.59 \pm 0.02 \mathrm{~mm}$.

The simultaneous depression of glycolysis and respiration was studied in the cornea of the living animal, using Krebs phosphate medium containing a concentration of $1 \times 10^{-3} \mathrm{M}$ iodoacetic acid and a concentration of $1 \times 10^{-3} \mathrm{M} \mathrm{DNP}$. 
The solution containing the mixture was dripped on the eye for $3 \mathrm{hrs}$, but no significant change in thickness of the cornea was observed. In two rabbits the mean weight of the control corneae was $94 \mathrm{mg}$. and at the end of the experimental period the experimental corneae weighed 3 and $12 \mathrm{mg}$. more than the control corneae. As no change in corneal thickness occurred no further experiments were made.

Two further compounds were also investigated. The first, mercuric chloride, has been shown to block active transport in skin at a concentration of $5 \times 10^{-4} \mathrm{M}$ (Linderholm, 1952) and in kidney slices at $3 \times 10^{-4} \mathrm{M}$ (Mudge, 1951); the second compound, 2-acetylamino-1 $: 3: 4$-thiadiazole-5-sulphonamide (Diamox, Lederle Laboratories), an inhibitor of the enzyme carbonic anhydrase, has been reported to inhibit active transport of ions in kidney and brain (Davies and Galston, 1952).

When the cornea of the excised eye was exposed to a concentration of $1 \times 10^{-3} \mathrm{M}$ mercuric chloride, the cornea turned opaque within $30 \mathrm{~min}$. and this was accompanied by a loosening of the epithelium; a similar loosening of the epithelial layer was observed at a concentration of $1 \times 10^{-4} \mathrm{M}$, while at $1 \times 10^{-5} \mathrm{M}$ no effect on corneal thickness or weight was observed. At this concentration the mean weights of the control and experimental corneae were $87 \cdot 8 \pm 3 \cdot 4(4)$ and $91 \cdot 3 \pm 4 \cdot 6(4) \mathrm{mg}$. after an experimental period of $5 \mathrm{hrs}$. In view of the marked toxic action of $\mathrm{HgCl}_{2}$ at $1 \times 10^{-4} \mathrm{M}$ and the lack of action at $1 \times 10^{-5} \mathrm{M}$, no further studies were made.

Diamox at concentrations up to $1 \times 10^{-3} \mathrm{M}$ had no action on the cornea of the excised eye; this concentration well exceeds that which was found by Maren, Mayer and Wadsworth (1954), strongly to inhibit the carbonic anhydrase activity of most tissues.

In the course of previous studies of the utilization of oxygen by the cornea (Langham, 1952) it was shown that if corneae were not exposed to the atmosphere for a period of 3-4 hrs there was a marked increase in the concentration of lactic acid in the cornea. At the same time the weights of these corneae were measured, and in some experiments the corneal thickness was also recorded. In no case was a change in corneal weight or thickness observed and the results were not published. However, in view of their interest to this investigation, the following results have been collected: in a series of eight experiments in which there was an increased concentration of lactic acid in the corneae denied atmospheric oxygen, the mean weights of the control and experimental corneae were $87 \cdot 4 \pm 2 \cdot 5 \mathrm{mg}$. and $89 \cdot 2 \pm$ $4 \cdot 2 \mathrm{mg}$. respectively.

It was considered that the lack of success in inducing a swelling of the cornea of the living rabbit in the above experiments might be due to the short experimental period. A series of experiments was, therefore, made on rabbits wearing contact lenses for longer periods. In three animals no increase in corneal thickness was observed in periods of $4 \mathrm{hrs}$, but in animals wearing lenses for $14 \mathrm{hrs}$ an increase of approximately 25 per cent. in the thickness and weight of the cornea was observed (Table VIII, opposite). To ascertain how much of this increase was due to an interference with aerobic metabolism, the rate of recovery after removal of the lens was investigated. The results, recorded in Table VIII, show that the curve of recovery comprised two distinct phases. In the first $2 \mathrm{hrs}$ there was a marked decrease in thickness and weight, the recovery being approximately 70 per cent. After this 2-hr period there was hardly any further change in the cornea during the following 
TABLE VIII

EFFECT OF WEARING A CONTACT LENS IN RABBITS. CONTACT LENS LEFT IN FOR 14 HRS AND CORNEAE ANALYSED AT 0, 2, 4, AND 6 HRS AFTER REMOVAL OF LENS

$C_{1}$ represents control eye and $C_{2}$ experimental eye

\begin{tabular}{|c|c|c|c|c|}
\hline Time (hrs) & Measurement & $\mathrm{C}_{1}$ & $\mathrm{C}_{2}$ & Difference $\left(C_{2}-C_{1}\right)$ \\
\hline 0 & $\begin{array}{l}\text { Thickness (mm.) } \\
\text { Weight (mg.) }\end{array}$ & $\begin{array}{r}0.42 \pm 0.01(7) \\
90.4 \pm 3.4 \text { (7) }\end{array}$ & $\begin{array}{r}0 \cdot 58 \pm 0.01(7) \\
113 \cdot 5 \pm 1 \cdot 4 \text { (7) }\end{array}$ & $\begin{array}{c}0 \cdot 16 \pm 0 \cdot 029 \\
23 \cdot 1 \pm 2 \cdot 2\end{array}$ \\
\hline 2 & $\begin{array}{l}\text { Thickness (mm.) } \\
\text { Weight (mg.) }\end{array}$ & $\begin{array}{r}0 \cdot 42 \pm 0.01 \text { (6) } \\
93 \cdot 8 \pm 6 \cdot 2 \text { (6) }\end{array}$ & $\begin{array}{r}0.48 \pm 0 \cdot 01 \text { (6) } \\
106 \cdot 2 \pm 7.9 \text { (6) }\end{array}$ & $\begin{aligned} 0 \cdot 0 & \pm 0 \cdot 020 \\
12 \cdot 4 & \pm 2 \cdot 5\end{aligned}$ \\
\hline 4 & $\begin{array}{l}\text { Thickness (mm.) } \\
\text { Weight (mg.) }\end{array}$ & $\begin{array}{l}0.42 \pm 0.01 \text { (6) } \\
91 \cdot 3 \pm 7 \cdot 4 \text { (6) }\end{array}$ & $\begin{array}{r}0.47 \pm 0 \cdot 01 \text { (6) } \\
105 \cdot 0 \pm 7 \cdot 1 \quad \text { (6) }\end{array}$ & $\begin{array}{c}0.05 \pm 0.007 \\
13.6 \pm 2.0\end{array}$ \\
\hline 6 & $\begin{array}{l}\text { Thickness (mm.) } \\
\text { Weight (mg.) }\end{array}$ & $\begin{array}{c}0.39 \pm 0.01(8) \\
81 \cdot 1 \pm 2.0 \quad(8)\end{array}$ & $\begin{array}{r}0.44 \pm 0.01 \text { (8) } \\
93.9 \pm 2.4 \text { (8) }\end{array}$ & $\begin{array}{l}0 \cdot 05 \pm 0 \cdot 010 \\
12 \cdot 8 \pm 1 \cdot 2\end{array}$ \\
\hline
\end{tabular}

$4 \mathrm{hrs}$, but after $24 \mathrm{hrs}$ the thickness had returned to its initial value. The phase of rapid recovery is similar to that observed in the presence of oxygen after a coldinduced swelling.

A study of similar changes in the corneae of a human subject who had been wearing contact lenses for 3 years showed that the thickness of the central area of both corneae increased from an initial value of $0.51 \mathrm{~mm}$. to $0.56 \pm 0.01 \mathrm{~mm}$. after wearing lenses for $5 \mathrm{hrs}$. This period was the subject's normal toleration time and after removal of the lens the cornea decreased to its initial value within 90 to $120 \mathrm{~min}$. The susceptibility of the corneae of this human subject and those of guinea-pigs (Smelser and Ozanics, 1953) contrasts with the greater resilience of the cornea of the rabbit observed in the present experiments.

In a final series of experiments, an attempt was made to lower the metabolism of the cornea of the living animal by dripping ice-cold Krebs phosphate medium on the cornea. The temperature of the epithelial surface dropped to $25^{\circ} \mathrm{C}$. and after $2 \frac{1}{2} \mathrm{hrs}$ the temperature of the endothelial surface was approximately $30^{\circ} \mathrm{C}$. In these conditions no increase in corneal thickness or wet weight was observed.

\section{Discussion}

The results of this investigation show that the aerobic but not the anaerobic metabolism of the epithelial and endothelial layers of the cornea, both in the living animal and in the excised eye, are essential to the regulation of hydration. However, the mechanism. by which aerobic metabolism actively effects a removal of salt and water from the cornea remains unsolved. In this respect, the application of well-known inhibitors of active transport systems to this problem has been unrewarding. 2:4 dinitrophenol and mercuric chloride, which inhibit the active transport of sodium ions across the epithelial layer of the skin without depressing its oxygen uptake, have influenced the cornea only at concentrations which depressed respiration or caused toxic reactions.

The extent to which metabolism may be reduced without causing a com- 
plete breakdown of the mechanism regulating corneal hydration is shown in the measurements of corneal swelling at different temperatures. In many biological tissues, the metabolic rate decreases by approximately one-half to two-thirds for a decrease in temperature of $10^{\circ} \mathrm{C}$., and if this is assumed to be true for the cornea the metabolic rate at $15^{\circ}$ and $25^{\circ} \mathrm{C}$. would be approximately $10-25$ and $35-50$ per cent. of that at $37^{\circ} \mathrm{C}$. At $25^{\circ} \mathrm{C}$. the metabolism was adequate to prevent a continuous corneal swelling, while at $15^{\circ} \mathrm{C}$. a steady state of corneal thickness was not maintained and the cornea slowly swelled to its maximal value of three to five times its normal thickness. On this basis, it might be concluded that the regulating mechanism breaks down if the metabolic rate decreases by approximately 80 per cent. However, this ignores a rather unexpected result in these experiments that the corneal thickness in conditions of steady state varied inversely with temperature. At $40^{\circ}, 37.5^{\circ}$, and $25^{\circ} \mathrm{C}$. the corneal thickness in conditions of steady state was 2,6 , and 15 per cent. above the initial thickness. Thus, at $25^{\circ} \mathrm{C}$., the metabolism was adequate to maintain the corneal thickness at 15 per cent., but not at 2 and 6 per cent., above the initial thickness. To explain this, it is necessary to assume that a decrease in the swelling pressure of the cornea accompanies a small increase in corneal thickness.

The action of DNP on the aerobic metabolic processes influencing corneal hydration differs in certain respects from its action in other tissues. An inhibition of the active transport of ions by DNP has been observed in gastric mucosa (Davies, 1951), kidney slices (Mudge, 1951), frog skin (Fuhrman, 1952), chicken erythrocytes (Maizels, 1954), plant cells (Robertson, Wilkins, and Weeks, 1951; Scott and Hayward, 1954), and nerve fibres (Hodgkin and Keynes, 1955). The mechanism of action is still unknown, but it is generally accepted that DNP has two principal effects on metabolism:

(i) It interferes with the transfer of energy-rich phosphate compounds from respiratory reactions to other processes;

(ii) It stimulates the respiratory rate.

In the present studies, DNP was observed to stimulate corneal respiration and also to decrease it at higher concentrations; a similar effect on smooth muscle has been observed by Born and Bülbring (1955).

It is evident from the studies of Mudge (1951) and other workers that the inhibition of the active transport of ions by DNP is not dependent on its effect on respiration, for it inhibits the active transport of ions in frog skin and kidneyslices at concentrations which increase the oxygen uptake. This was not found to hold good for the cornea, where the swelling rate appeared to be dependent on the inhibition of the oxygen uptake. At the same time, concentrations of DNP which increased the oxygen uptake of the cornea caused no swelling. If, therefore, DNP inhibits an active transport mechanism in the cornea, it is evident that the secretory and respiratory aspects of this mechanism cannot be dissociated by this compound. 
On the other hand, DNP may not inhibit the active transport mechanism at all, but may cause swelling by decreasing the respiratory activity. This possibility is increased by the finding that mercuric chloride at concentrations which also inhibit the active transport of ions in skin and kidney slices with a concurrent increase in the respiration of the tissues does not cause corneal swelling.

An explanation of the differences between the response of tissues to DNP may eventually be found in varying patterns of metabolism. The recent studies of Kinoshito and Masurat (1954) have shown that two pathways exist for the oxidation of glucose in extracts of corneal epithelium, and that the direct oxidative cycle is likely to account for the major portion of the oxygen uptake. This would seem to single out the cornea as a tissue differing from many whose main respiratory activity is dependent on the well-known glycolytic citric acid cycle of metabolism. In the present studies a depression of oxygen uptake of approximately 20 per cent. by DNP caused a swelling of the cornea, and yet iodoacetic acid and sodium fluoride (unpublished experiments) failed to induce a swelling of the cornea in the presence of oxygen even when glycolysis was inhibited by 80 per cent. It is therefore quite possible that the influence of aerobic metabolism on corneal hydration is determined principally by the activity of the direct oxidative cycle.

In attempting to explain the inability of either DNP or oxygen-lack to influence corneal hydration in the living animal over an experimental period up to $5 \mathrm{hrs}$, it is reasonable to assume that corneal metabolism and particularly the metabolism of the epithelium was affected by the experimental techniques. DNP was given in concentrations well exceeding those that gave a maximal increase in hydration in the excised eye, and in the conditions of the experiment led to cataractous changes in the lens; similarly, lack of oxygen to the epithelium resulted in changes in the concentration of lactic acid in the cornea (Langham, 1952). There are, however, several factors which could contribute to account for this difference:

(i) The intra-ocular pressure acting on the cornea may oppose the swelling pressure in the stroma and thus decrease the tendency of the cornea to swell.

(ii) The permeability of the cornea to water and electrolytes is minimal in the living animal, and consequently the work required to move water and electrolytes out of the cornea would be less than in the excised eye.

(iii) It is probable that the secretory mechanism regulating corneal hydration acts across the endothelial as well as the epithelial layer and the interchange of water and electrolytes between the endothelium and the aqueous humour would be facilitated by the circulation of the aqueous humour.

From our experiments on both the excised eye and the living animal, it appears unlikely that anaerobic metabolism contributes to the movement of water and salt from the cornea, for the rate of corneal swelling in the absence of oxygen was unchanged in the presence of a concentration of iodoacetic acid which inhibited glycolysis by over 75 per cent. The contrary view, 
based on similar experiments using higher concentrations of iodoacetic acid (Schwartz, Danes, and Leinfelder 1954; Philpot, 1955), may be explained as being due to an increase in the permeability of the cornea. Iodoacetic acid has been shown by Herrmann and Hickman (1948) to loosen the adhesion of the epithelial layer to the underlying stroma, and the present results have shown that this occurs at the concentrations used by these workers.

Studies of the movement of water and salt into and out of the cornea serve to emphasize the cardinal role played by aerobic metabolism in regulating corneal hydration. The swelling and deturgescence of the cornea of the excised eye have been accompanied by a movement of sodium and water. In the absence of oxygen the movement of salt into the cornea is depressed for a limited time, which could mean either that some oxygen remained or that, as Smelser and Ozanics (1953) suggest, an energy reserve exists which may prevent corneal swelling for a limited period. The first explanation is considered improbable, as the medium was deoxygenated before the start of the experiment and the oxygen in the eye itself would only maintain corneal respiration for a very short time. Attempts to identify an energy reserve with the presence of glycogen in the epithelial cells of the rabbit, in a manner similar to that described by Smelser and Ozanics (1953) in guinea-pigs, were not successful, possibly because of the very low concentration of glycogenstainable material found in the normal rabbit cornea.

Since the removal of salt and water from the cornea is dependent on aerobic metabolism. and since respiration is limited, almost, if not completely, to the epithelial and endothelial layers (Langham, 1952, 1954), it is most likely that the bulk movement of water and salt from the stroma is determined by a secretory process acting across one or both of these layers. An alternative hypothesis, that the water content of the stromal colloid is determined by its own metabolism, is contraindicated by all experimental evidence. This conclusion is supported especially by two observations:

(i) the isolated corneal stroma increases in weight at a similar rate in anaerobic and aerobic conditions;

(ii) if the epithelial layer is removed from the cornea of the living animal, the central area, which is the last to regain its epithelium., maintains its degree of swelling even though over 90 per cent. of the corneal area has fully recovered its normal thickness.

On this basis, certain characteristics of the postulated secretory mechanism as it acts in the epithelial layer may be visualized. In the epithelium of the rabbit, the basal layer forms a complete palisade bordering the stroma, and the next outer layer shows early signs of cornification and stratification. It is therefore probable that the secretory mechanism. is maintained by the aerobic metabolic processes and the energy reserve within the first layer of cells. The action of this secretion is to transfer salt and water from. the stromal fluid. First, there may be a direct active transport of water across the cell layers, which causes the salts in the stromal fluid to be hypertonic to the outside 
medium and leads to a tendency to lose salts by outward diffusion. In this case the active transport of water across the cell layer could be independent of, or dependent on, the active transport mechanism maintaining the high concentration of potassium and the low concentration of sodium in the cell. The results in this paper are consistent with this scheme. Secondly, it is conceivable that there is a direct active transport of sodium or an anion from the stromal fluid. In this case it is difficult to visualize how the maintenance of a high potassium and low sodium concentration within the epithelial cells could be consistent with a transcellular net movement of sodium; on the other hand, a peri-cellular active transport of sodium is a possibility. Attempts to identify an active transport of anions from the stroma to the epithelium have been unsuccessful (Friedenwald, 1948), and the finding that Diamox, a powerful carbonic anhydrase inhibitor, does not increase the hydration of the cornea suggests that the transfer of bicarbonate is not involved in the secretion. Thus, although the active transport of sodium or an anion from the stromal fluid cannot be discounted, there is indirect experimental support for a scheme involving an active transport of water across the epithelial cells in an outward direction.

The concurrent analyses of the concentrations of sodium and the specific activities of radioactive sodium $\left({ }^{24} \mathrm{Na}\right)$ in the cornea, the aqueous humour, and the plasma indicate that the transfer of sodium into the cornea and the aqueous humour from the plasma very nearly attains a state of dynamic equilibration within $20 \mathrm{hrs}$. At this time, the steady-state concentration ratio between the aqueous humour and the plasma or the cornea for ${ }^{24} \mathrm{Na}$ is within 1-2 per cent. of that found for the total sodium. The value observed for the steady-state concentration ratio between the aqueous humour and the plasma, namely 0.93 to 0.94 , agrees with the mean value reported by Kinsey and Bárány (1949) using ${ }^{24} \mathrm{Na}$, but is significantly less than the value of 0.98 reported by Kinsey (1950) from analyses of the total sodium in pooled samples of aqueous humour and plasma. It is widely accepted that the concentration of sodium in the aqueous humour is 1-2 per cent. in excess of that required by a thermodynamic equilibration between the plasma and its ultrafiltrate, and it therefore follows that the theoretical distribution ratio $\mathrm{Na}_{\mathrm{aq}} / \mathrm{Na}_{\mathrm{pl}}$ in the absence of metabolic activity would be 0.91 to 0.93 . Such a value would be in close agreement with the findings of Ingraham, Lombard, and Visscher (1933) on the distribution of ions between the plasma and its ultrafiltrate. These workers observed that the mean ratio of the concentrations of sodium in the plasma water and its ultrafiltrate was 0.928 at $p \mathrm{H} 7.0$ and

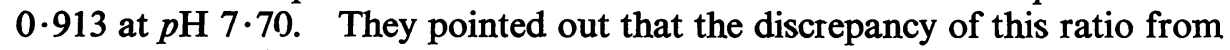
unity could not be completely accounted for by the base-binding capacity of the plasma proteins, and suggested, from a comparison of the effect of $p H$ on the distribution ratios of several cations, that the low ratio was partly caused by a depression of the activity coefficients of all cations by the plasma proteins. 
The high concentration of sodium in the cornea of the rabbit compared with that in the plasma and the aqueous humour agrees with the findings of Davson (1949) in cattle eyes. Presumably, this is mainly due to the basebinding capacity of the mucopolysaccharide protein complex comprising the extracellular volume of the cornea. An approximate measure of the extracellular and intracellular volumes of the cornea may be ascertained if it is assumed that the concentration of potassium within the cells is equal to that of sodium in the plasma water, and that the concentration of potassium in the extracellular water equals that in the plasma water. With these provisos the present results indicate that the intracellular volume occupies approximately 14 per cent. of the total volume; this is in agreement with the value for cattle corneae calculated by Davson (1949). The corneal cells are found predominantly in the epithelial and endothelial layers which comprise 10-11 per cent. of the cornea (Maurice, 1951; Langham, 1952).

\section{Summary}

(1) The concentrations of sodium in the cornea, aqueous humour, and plasma of the living rabbit eye have been determined. The distribution of sodium between the three tissues has been compared with concurrent analyses of the activity of radioactive sodium $\left({ }^{24} \mathrm{Na}\right) 20 \mathrm{hrs}$ after an intravenous injection of a solution of a radioactive salt. At this time the distribution ratios for ${ }^{24} \mathrm{Na}$ were within a few per cent. of that found for total sodium. The results are discussed in relation to previous studies with ${ }^{24} \mathrm{Na}$.

(2) The effect of temperature on the rate and extent of corneal swelling in the presence of oxygen has been determined. In the range of temperatures from 25 to $37 \cdot 5^{\circ} \mathrm{C}$. the corneal thickness increased to a new state of dynamic equilibrium. At the same time, the extent of corneal swelling varied inversely with the decrease in temperature. At $15^{\circ} \mathrm{C}$. the decreased metabolism was inadequate to prevent a continued swelling of the cornea. It is suggested that the increase in corneal thickness is accompanied by a marked decrease in the swelling pressure of the cornea.

(3) The rate of increase in corneal thickness and the net movement of sodium into and out of the cornea of the excised eye immersed in Krebs phosphate saline medium at $37.5^{\circ} \mathrm{C}$. in the presence or absence of oxygen have been determined. The extent of corneal swelling in the first $2 \frac{1}{2} \mathrm{hrs}$ after enucleation was only slightly increased by the absence of oxygen. After this period a significant and sustained swelling of the cornea took place in the absence of oxygen; in the same period no corneal swelling occurred in the presence of oxygen. These results confirm the view that the maintenance of hydration is dependent on corneal respiration, and are consistent with the view that in the absence of oxygen there is sufficient energy reserve in the cornea of the excised eye to prevent swelling for $2-3 \mathrm{hrs}$. 
(4) Observations have been made of the rate and extent of recovery of the cornea from a swollen state induced by cooling. In the absence of oxygen no recovery was observed. In aerobic conditions recovery was nearly complete within 2-5 hrs, and was accompanied by movement of sodium out of the cornea at a rate of $1 \cdot 24 \times 10^{-8} \mathrm{~mol}$. min. ${ }^{-1}$ per $100 \mathrm{mg}$. wet tissue.

(5) The effect of $2: 4$ dinitrophenol on the metabolism and hydration of the cornea of the excised eye has been studied. At low concentrations it stimulated and at higher concentrations it depressed the respiration. No effect on anaerobic glycolysis was observed at concentrations up to $1 \times 10^{-3} \mathrm{M}$. In the presence of oxygen this compound caused a swelling of the cornea of the excised eye, an effect which appeared mainly dependent on its effect on corneal respiration.

(6) Similar studies were made with three other compounds which interfere with the active transport mechanisms of other tissues, namely, iodoacetic acid, mercuric chloride, and 2-acetylamino-1 $: 3: 4$-thiadiazole-5 sulphonamide*, which is an inhibitor of carbonic anhydrase. Both iodoacetic acid and mercuric chloride were found to loosen the adhesion of the epithelial layer to the underlying stroma at very low concentrations and to result in a gross increase in corneal permeability; at more dilute concentrations no effect on corneal hydration was observed. Diamox had no effect on corneal . hydration.

(7) In the living animal, iodoacetic acid, with or without $2: 4$ dinitrophenol in concentrations sufficient to result in a marked depression of glycolysis and respiration, had no effect on the thickness and weight of the cornea during periods of $2 \frac{1}{2}$ to $5 \mathrm{hrs}$.

(8) In the rabbit the wearing of a contact lens induced corneal swelling which -was rapidly reversed on removing the lens. In a humare subject wearing a contact lens, swelling was induced more readily than in rabbits, and again recovery took place rapidly on removal of the lens. The rate of recovery is consistent with a removal of water and salt from the cornea by an active process dependent on the aerobic metabolism in the epithelial layer.

We wish to thank Sir Stewart Duke-Elder for his interest and advice during the course of this work, and the Medical Research Council for defraying the cost of the research. I. S. Taylor is indebted to the National Institute of Neurological Diseases and Blindness of the National Institute of Health, U.S. Public Health Service, for a traineeship award.

\section{REFERENCES}

BORN, G. V. R., and Bülbring, E. (1955). J. Physiol. (Lond.), 127, 626.

DAVIES, R. E. (1951). Biol. Rev., 26, 87.

, and Galston, A. W. (1952). "The Role of Carbonic Anhydrase in Ion Transport".

II. Congr. Int. Biochimie, Paris, 1952, p. 142, Résumés des communications. Masson, Paris. Davson, H. (1949). British Journal of Ophthalmology, 33, 175. (1954). J. Physiol. (Lond.), 125, 15P. (1955). Biochem. J., 59, 24. 
Dixon, M. (1951). “ Manometric Methods", 3rd ed. University Press, Cambridge.

DuANE, T. D. (1949). Amer. J. Ophthal., 32, June, Pt. 2, p. 203.

FRIEDENWALD, J. S. (1948). Bull. Johns Hopk. Hosp., 82, 326.

Futrman; F. A. (1952). Amer. J. Physiol., 171, 266.

HeALD, K, and Langham, M. E. (1953). J. Physiol. (Lond.), $122,15$.

(1956). Ibid., in the press.

HerRmanN, H., and HickMAN, F. H. (1948). Bull. Johns Hopk. Hosp., 82, 213.

HodGKIN, A. L., and KeYNes, R. D. (1955). J. Physiol. (Lond.), 128, 28.

InGRAham, R. C., Lombard, C., and Visscher, M. B. (1933). J. gen. Physiol., 16, 637.

KinOShita, J. H., and MASURAT, T. (1954). Arch. Biochem, , 53, 9.

KINSEY, V. E., and BÁRÁNY, E. (1949). Amer. J. Ophthal., 32, June, Pt. 2, p. 189. (1950). Arch. Ophthal. (Chicago), 44, 215.

LANGHAM, M. E. (1951). J. Physiol. (Lond.), 115, 65P. (1952). Ibid., 117, 461 .

(1954). Ibid., 126, 396.

(1955a). XVII Concilium Ophthalmologicum 1954. Canada, United States of America.

Acta, Vol. 1, p. 500 . University of Toronto Press. (1955b). J. Physiol. (Lond.), 128, 43.

LINDERHOLM, H. (1952). Acta physiol. scand.; 27, Suppl. 97, pp. 1-44.

MaIZeLS, M. (1954). Soc. exp. Biol., 8, 202.

MAREN, T. H., MAYER, E., and WADSWORTH, B. C. (1954). Bull. Johns Hopk. Hosp., 95, 199.

MAURICE, D. M. (1951). J. Physiol. (Lond.), 112, 367.

, and GIARDINI, A. A. (1951). British Journal of Ophthalmology, 35, 169.

MUdGe, G. H. (1951). Amer. J. Physiol., 167, 206.

PHILPOT, F. J. (1955). J. Physiol. (Lond.), 128, 504.

Robertson, R. N., WilkINs, M. J., and WeEks, D. C. (1951). Aust. J. sci. Res., Ser. B, 4, 248.

SCHWARTZ, B., DANES, B., and LeINFELDER, P. J. (1954). Amer. J. Ophthal., 38, July, pt. 2, 182.

SCOTT, G. T., and HAYWARD, H. R. (1954). J. gen. Physiol., 37, 601.

SMELSER, G. K. (1952). A.M.A. Arch. Ophthal., 47, 328. and Ozanics, V. (1952). Science, 115, 140. (1953). A.M.A. Arch. Ophthal., 49, 335.

UMBREIT, W. W., BURRIS, R. H., and STAUFFER, J. F. (1949). "Manometric Techniques and Tissue Metabolism ". Burgess, Minneapolis. 